\title{
Study of Pavement Condition Index (PCI) relationship with International Roughness Index (IRI) on Flexible Pavement.
}

\author{
Rijal Psalmen Hasibuan ${ }^{1 *}$, and Medis Sejahtera Surbakti ${ }^{*}$ \\ ${ }^{1}$ Graduate Student, Civil Engineering Department, Universitas Sumatera Utara, Indonesia \\ ${ }^{2}$ Lecture, Civil Engineering Department, Universitas Sumatera Utara, Indonesia
}

\begin{abstract}
Road is an infrastructure that built to support the movement of the vehicle from one place to another for different purposes. Today, it is often found damage to road infrastructure, both local roads, and arterial roads. Therefore, to keep the pavement condition to remain reliable, in Indonesia has a periodic program by conducting an objective functional inspection of roads regulated by Bina Marga using the International Roughness Index (IRI). However, the IRI examination is not sufficient to represent the actual field condition; it is necessary to perform subjective functional examination by appraising the road one of them is Pavement Condition Index (PCI, ASTM D 6433). This method has been widely applied in some countries because it has many advantages. However, to do this inspection requires considerable cost, then there needs to be a model to get the relationship between these two parameters of the road. The selected case study was arterial road segment in Medan City, that is in Medan inner ring road. Based on the results of the analysis, there is a difference between the functional conditions of PCI and IRI. The equation derived from these two parameters is by exponential regression equation, with equation IRI $=16.07 \mathrm{exp}^{-0.26 \mathrm{PCI}}$ . with $\mathrm{R}^{2}$ of $59 \%$ with correlation coefficient value $(\mathrm{r})$ of -0.768 . The value of $\mathrm{R}^{2}$ indicates that PCI gives a strong influence on IRI value.
\end{abstract}

\section{Preliminary}

Nowadays, it is often found damage to road infrastructure, both local roads, and arterial roads. The condition, of course, will also disturb the convenience and endanger the road users. Technically, road damage indicates a situation where the structural and functional roads are not able to provide optimum service to the traffic crossing the road. In general, the functional performance of the path can be determined by 2 (two) ways, i.e., objectively and subjectively. Objectively, pavement performance is obtained from a measurement using roughness measuring instrument, whereas in a subjective way it is based on the observation of several experts directly in the field (Suwardo, 2004). One parameter of pavement performance that can be objectively determined is roughness and can be subjectively determined by assigning a value to Pavement Condition.

In Indonesia, the road functional appraisal method is issued by DGH. This method assesses pavement level conditions by combining the value of International Roughness Index with Surface Distress Index (SDI). However, some studies show that SDI tends not to represent the real state of affairs, so a survey method that is more likely to describe the actual functional conditions of the road, one of them is Pavement Condition Index (PCI). However, this PCI functional survey method requires time, cost and labor not a little. With such regular road conditions, it is necessary to create a model illustrating the relationship between IRI and PCI values, thereby improving the results of better identification of the functional conditions of the roads to make appropriate decisions for the road conditions.

\section{Literature Study}

\subsection{Pavement Condition Index (PCI, ASTM D 6433)}

Pavement Condition Index (PCI) is a method of assessing pavement conditions developed by U.S Army Corps of Engineer, expressed in the Pavement Condition Index (PCI) index. The use of PCI for the evaluation of airport pavements, roads and parking lots has been widely used in the United States. In the PCI method, the degree of pavement damage is a function of 3 main factors, namely:

\footnotetext{
* Corresponding author: rphasibuan@gmail.com
} 


\section{Distress type}

According to Shahin (1994), there are 19 (Nineteen) types of damage to the flexible pavement in the PCI method, among which are: alligator cracking, bleeding, block cracking, bumps and sags, corrugation, depression, edge cracking, joint reflection cracking, lane/shoulder drop off, longitudinal \& transversal crack, patching and utility cut patching, polished aggregate, potholes, railroad crossing, rutting, shoving, slippage cracking, swell, weathering / raveling.

\section{Distress severity}

The severity of pavement damage on the PCI method, divided into 3 (three) levels, namely low (1), medium (m) and high (h). Determination of the severity for the type of damage has been defined by the PCI method clearly in accordance with ASTM D 6433.3.

\section{Distress quantity}

Distress quantity relates to measurement, measurement unit and total quantities on survey form.

\begin{tabular}{|c|c|c|}
\hline No & Type of Damage & Unit \\
\hline 1 & Alligator Cracking & $\mathrm{m}^{2}$ \\
\hline 2 & Bleeding & $\mathrm{m}^{2}$ \\
\hline 3 & Block Cracking & $\mathrm{m}^{2}$ \\
\hline 4 & Bumps and Sags & $\mathrm{m}$ \\
\hline 5 & Corrugation & $\mathrm{m}^{2}$ \\
\hline 6 & Depression & $\mathrm{m}^{2}$ \\
\hline 7 & Edge Cracking & $\mathrm{m}$ \\
\hline 8 & Jt. Reflection Cracking & $\mathrm{m}$ \\
\hline 9 & Lane Shoulder Drop Off & $\mathrm{m}$ \\
\hline 10 & Long. \& Trans. Cracking & $\mathrm{m}$ \\
\hline 11 & Patching \& Utility Patching & $\mathrm{m}^{2}$ \\
\hline 12 & Polished Aggregate & $\mathrm{m}^{2}$ \\
\hline 13 & Potholes & number \\
\hline 14 & Rail Road Crossing & $\mathrm{m}^{2}$ \\
\hline 15 & Rutting & $\mathrm{m}^{2}$ \\
\hline 16 & Shoving & $\mathrm{m}^{2}$ \\
\hline 17 & Slippage Cracking & $\mathrm{m}^{2}$ \\
\hline 18 & Swell & $\mathrm{m}^{2}$ \\
\hline 19 & Weathering / Ravelling & $\mathrm{m}^{2}$ \\
\hline
\end{tabular}

Source: Shahin (2004)

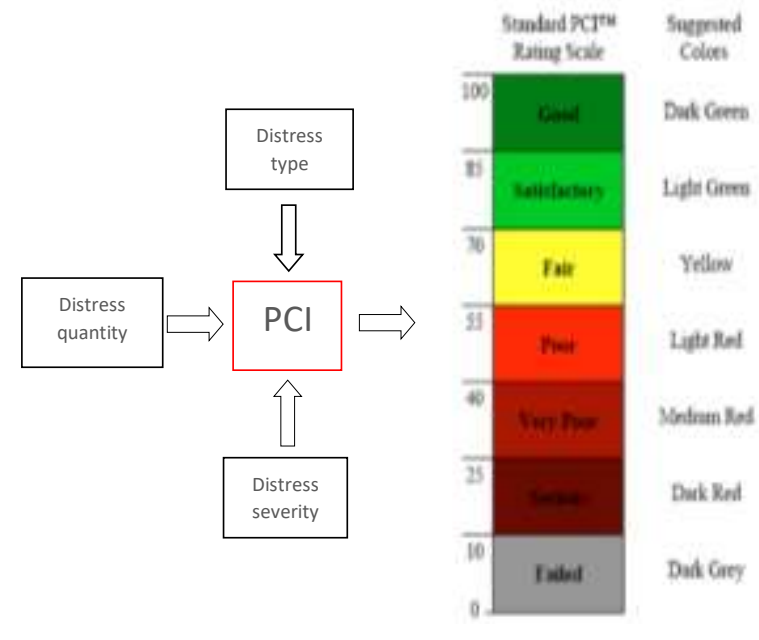

Fig. 1. Relationship type of damage, severity, and size of damage to the determination of PCI value and Standard Rating Scale (Source: Shahin 2004)

Assessment of Pavement Conditions, influenced by 5 factors, namely:

1. Density

2. Deduct Value (DV)

3. Total Deduct Value (TDV)

4. Corrected Deduct Value (CDV)

5. Pavement Quality Qualified

\subsection{International Roughness Index (IRI)}

International Roughness Index (IRI) is a parameter used by the world bank for in the process of assessing the condition of pavement in 1980. Unevenness is a prolonged profile picture of the pavement which is a picture of the comfort of driving on the highway. This quantitative value of unevenness is expressed in the International Roughness Index (IRI), i.e., the cumulative length of rising and fall of the surface per unit length in which IRI units are shown in meters down the length of road miles $(\mathrm{m} / \mathrm{km})$.

Table 2. Rating Scale on PCI method

\begin{tabular}{cc}
\hline IRI Scale $\mathbf{~ m} / \mathbf{k m}$ & Pavement Criteria \\
\hline $\mathbf{0}-\mathbf{2}$ & Very Good \\
\hline $\mathbf{2}-\mathbf{4}$ & Good \\
\hline $\mathbf{4}-\mathbf{6}$ & Fair \\
$\mathbf{6 - 8}$ & Poor \\
\hline $\mathbf{8}-\mathbf{1 0}$ & Very Poor \\
\hline
\end{tabular}

Source: ASTM D 1926

Currently, several tools used for IRI data retrieval, some of which are: Roughometer NAASRA, dipstick, rolling - straight edge, MERLIN, profilograph, Hawkeye, Roughometer III, and so forth. 


\section{Research Methodology}

\subsection{Research sites}

This research was conducted in one of the inner ring road in Medan city, starting from Gagak Hitam Street (Sunggal Intersection) to Asrama Street to Kapten Sumarsono Street (Kapten Muslim intersection) which is included in the category of National Road under the management of the National Implementation Center II Medan Medan (BBPJN II Medan)..

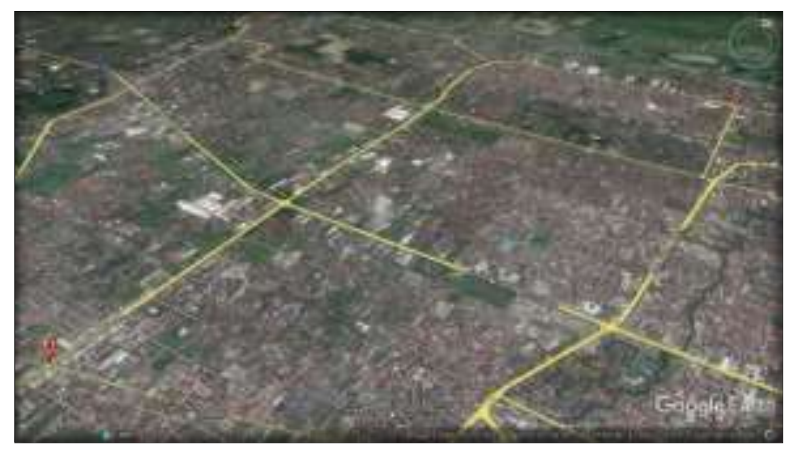

Fig. 2. Location of research on Jalan Gagak Hitam, Medan

\subsection{Data collection and analysis}

Data collection was done in the field, i.e., functional road examination by PCI and IRI method divided into 50 meters. PCI survey with reference ASTM D6433, while for the review of roughness (IRI) using Roughometer III tool obtained from BBPJN II Medan. The analysis of the relationship between the two parameters is done by using SPSS commercial software, which is done by making the regression equation in some equation. That gives the value of $\mathrm{R}^{2}$ used as the result of the equation of the two relations.

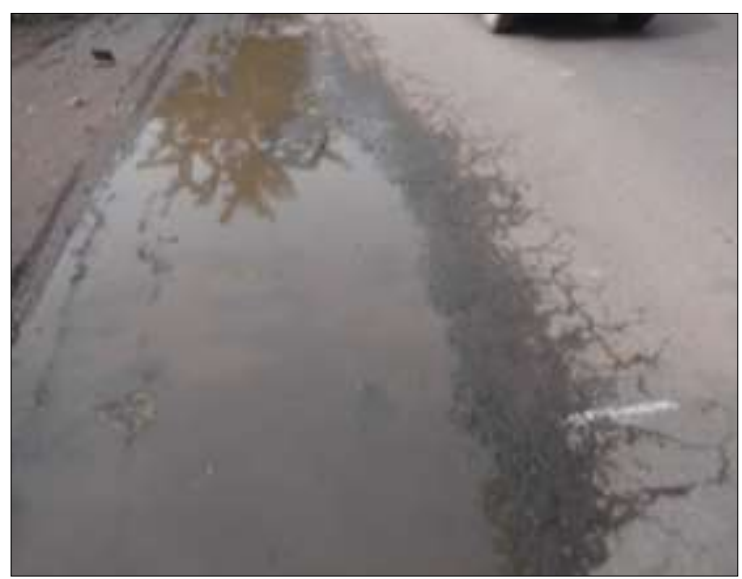

(a)

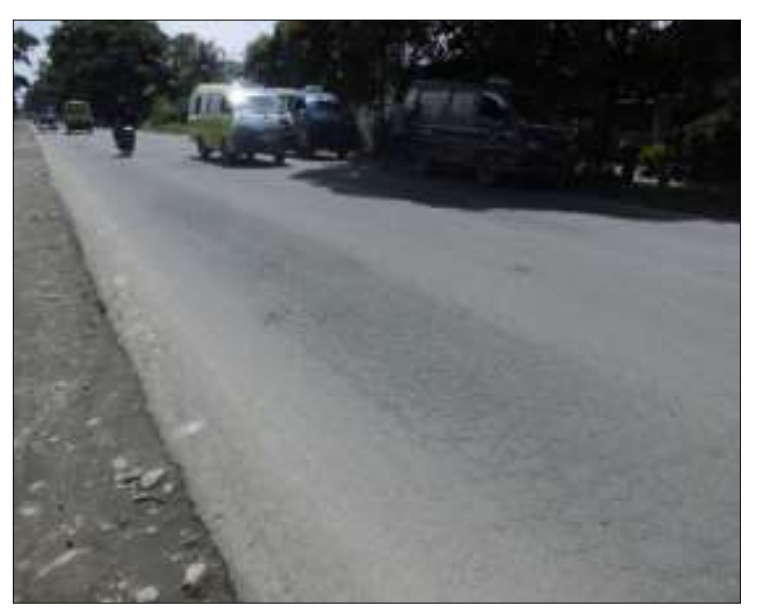

(b)

Fig. 3. Sample survey of road conditions; (a) edge cracking combine with depression, (b) alligator cracking

\subsection{Roughometer III}

Roughometer III is a device that measures the ruggedness by eliminating the effect of the used vehicle components, such as suspension or passenger load, i.e., by directly measuring the shaft movement with the Accelerometer precision.

Noteworthy in the installation of this tool is that all components must be installed in place, and calibration before use must be tailored to the needs.

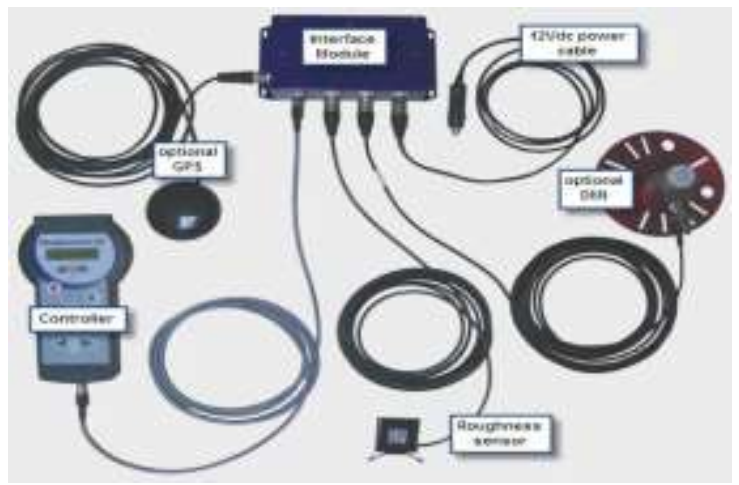

Fig. 4. Component of Roughometer III

\section{Result and Discussion}

\subsection{Analysis of road condition assessment with $\mathrm{PCl}$}

The steps to get the PCI value are as follows:

1. Determination of deduct values

2. Determination of the maximum allowable deduct number $(m)$

3. Maximum CDV Determination

4. PCI value calculation deduct values 
Table 3. Functional Condition of PCI per segment road location

\begin{tabular}{|c|c|c|c|c|}
\hline No & $\begin{array}{c}\text { Road } \\
\text { Segment }\end{array}$ & $\begin{array}{l}\text { Length } \\
\text { (m) }\end{array}$ & $\begin{array}{c}\text { PCI } \\
\text { (Average) }\end{array}$ & $\begin{array}{c}\text { Road } \\
\text { Condition }\end{array}$ \\
\hline 1 & $\begin{array}{c}\text { Gagak } \\
\text { Hitam Street } \\
\text { (Sunggal } \\
\text { Intersection) }\end{array}$ & 850 & 71.87 & Satisfactory \\
\hline 2 & $\begin{array}{c}\text { Asrama } \\
\text { Street }\end{array}$ & 1500 & 60.8 & Fair \\
\hline 3 & $\begin{array}{c}\text { Kapten } \\
\text { Sumarsono } \\
\text { Street } \\
\text { (Kapten } \\
\text { Muslim } \\
\text { Intersection) }\end{array}$ & 2650 & 53.53 & Poor \\
\hline
\end{tabular}

However, for overall PCI functional assessment, the location of this study is categorized as a Fair road segment, where PCI values range from 55 to 70 .

\subsection{Analysis of road condition assessment with IRI}

IRI examination results are done by connecting controller Roughometer III with computer, then obtained the results of the examination.

Table 4. Functional Condition IRI per Road Segment

\begin{tabular}{|c|c|c|c|c|}
\hline No. & $\begin{array}{c}\text { Road } \\
\text { Segment }\end{array}$ & $\begin{array}{l}\text { Length } \\
\text { (m) }\end{array}$ & $\begin{array}{c}\text { IRI } \\
\text { (Average) }\end{array}$ & $\begin{array}{c}\text { Road } \\
\text { Condition }\end{array}$ \\
\hline 1 & $\begin{array}{c}\text { Gagak } \\
\text { Hitam } \\
\text { Street } \\
\text { (Sunggal } \\
\text { Intersection) }\end{array}$ & 850 & 2.38 & Good \\
\hline 2 & $\begin{array}{l}\text { Asrama } \\
\text { Street }\end{array}$ & 1500 & 3.6 & Good \\
\hline 3 & $\begin{array}{c}\text { Kapten } \\
\text { Sumarsono } \\
\text { Street } \\
\text { (Kapten } \\
\text { Muslim } \\
\text { Intersection) }\end{array}$ & 2650 & 4.3 & Fair \\
\hline
\end{tabular}

However, to determine the overall functionality that the PCI survey has undertaken, the location of this study is categorized as a Good road segment, where the IRI value is between $2-4 \mathrm{~m} / \mathrm{km}$.

\subsection{Analysis of $\mathrm{PCI}$ relationship with IRI}

\begin{tabular}{|c|c|c|c|c|}
\hline No & $\begin{array}{c}\text { Road } \\
\text { Segment }\end{array}$ & $\begin{array}{c}\text { PCI } \\
\text { (Average) }\end{array}$ & $\begin{array}{c}\text { IRI } \\
\text { (Average) }\end{array}$ & $\begin{array}{c}\text { The type } \\
\text { of damage } \\
\text { that } \\
\text { dominates }\end{array}$ \\
\hline 1 & $\begin{array}{c}\text { Gagak } \\
\text { Hitam } \\
\text { Street } \\
\text { (Sunggal } \\
\text { Intersec- } \\
\text { tion) }\end{array}$ & 71.87 & 2.38 & Rutting \\
\hline 2 & $\begin{array}{c}\text { Asrama } \\
\text { Street }\end{array}$ & 60.8 & 3.6 & $\begin{array}{l}\text { Alligator } \\
\text { cracking, } \\
\text { rutting, } \\
\text { ravelling }\end{array}$ \\
\hline 3 & $\begin{array}{c}\text { Kapten } \\
\text { Sumarso- } \\
\text { no Street } \\
\text { (Kapten } \\
\text { Muslim } \\
\text { Intersec- } \\
\text { tion) }\end{array}$ & 53.53 & 4.3 & $\begin{array}{c}\text { Alligator } \\
\text { cracking, } \\
\text { rutting, } \\
\text { lane } \\
\text { sholder } \\
\text { off, } \\
\text { potholes }\end{array}$ \\
\hline
\end{tabular}

Table 6. Functional Condition of PCI and IRI per Road Location Study Area

There are several types of relationship model between IRI and PCI, all of which will give a coefficient of determination value $\left(\mathrm{R}^{2}\right)$, in this research, the most significant value of $\mathrm{R}^{2}$ with exponential equation.

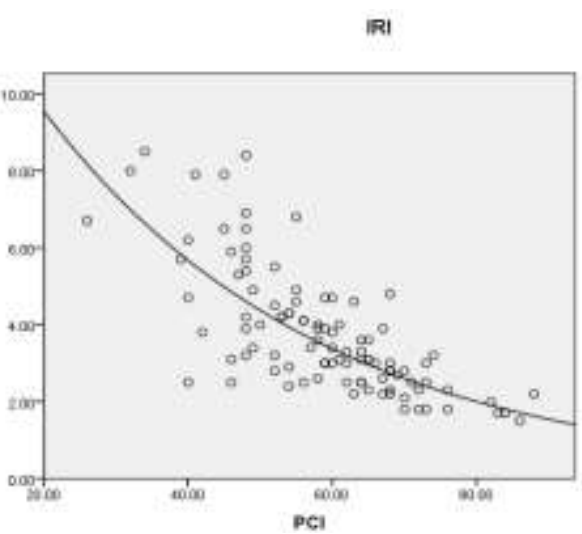

OQ Otonerved

Fig. 5. The relationship equation between PCI and IRI values

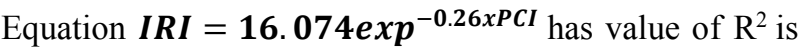
$59 \%$ and correlation coefficient value $(\mathrm{r})$ is -0.768 . 
Table 6. Coefficient Determination Recapitulation at Study

\begin{tabular}{|c|c|c|c|c|}
\hline \multirow{3}{*}{ No } & \multicolumn{4}{|c|}{ Area } \\
\hline & & \multicolumn{2}{|c|}{ Road Assessment } & \multirow{2}{*}{$\mathbf{R}^{2}$} \\
\hline & & PCI & IRI & \\
\hline 1 & $\begin{array}{l}\text { Gagak Hitam } \\
\text { Street (Sunggal } \\
\text { Intersection) }\end{array}$ & $\begin{array}{c}\text { Satisfac- } \\
\text { tory }\end{array}$ & Good & $71.0 \%$ \\
\hline 2 & Asrama Street & Fair & Good & $46.8 \%$ \\
\hline 3 & $\begin{array}{c}\text { Kapten } \\
\text { Sumarsono } \\
\text { Street (Kapten } \\
\text { Muslim } \\
\text { Intersection) }\end{array}$ & Poor & Fair & $44.3 \%$ \\
\hline
\end{tabular}

$\mathrm{R}^{2}$ tends to decrease due to road damage which because of this road has a road characteristic of its own. For Gagak Hitam street, which has four lanes and two directions, it is dominated by light vehicles. As for the 1.5 $\mathrm{km}$ Asrama street, it is dominated by heavy vehicles entering from Binjai City, so it has different traffic loads with Gagak Hitam street. In contrast to Kapten Sumarsono's street, there is a narrowing of the road which is laid to the previous road four lanes, narrowing into 2 lanes 2 directions without a median. This implies that the traffic load tends to increase.

\section{Conclusion and recommendation}

\subsection{Conclusion}

1.Following the division of the Rating Scale Pavement Condition Index, the road segment in the study location is classified as fair, with an average PCI value of 58.6. The dominant types of damage are rutting, alligator cracking, patching \& cut utility, and lane/shoulder off. Meanwhile, based on the IRI assessment, the road segment is classified as a good quality road, with an IRI score ranging from 2 to 4 .

2. In addition to differences in the scoring scale, the IRI values obtained tend to be less close to the field conditions. This is because the value of IRI is obtained from the amount of rise and fall of the roughness sensor mounted on the axle of the survey vehicle so as to cause the sensor to read only the surface of the road through the wheels of the vehicle.

3. Based on the value of the coefficient of determination, the relationship between PCI and IRI is quite strong. The value of $\mathrm{R} 2$ of 0.59 indicates that $59.0 \%$ of PCI value has an IRI value, and R-value is -0.768 , which means that the correlation level of these two parameters is strong but opposite.

\subsection{Recommendation}

Concerning the results of this study, some suggestions may be given as follows:

1. Following the division of the Rating Scale Pavement Condition Index, the road segment in the study location is classified as fair, with an average PCI value of 58.6. The dominant types of damage are rutting, alligator cracking, patching \& cut utility, and lane/shoulder off. Meanwhile, based on the IRI assessment, the road segment is classified as a good quality road, with an IRI score ranging from 2 to 4 .

2. In addition to differences in the scoring scale, the IRI values obtained tend to be less close to the field conditions. It is because the value of IRI is derived from the amount of rising and fall of the roughness sensor mounted on the axle of the survey vehicle to cause the sensor to read only the surface of the road through the wheels of the car.

3. Based on the value of the coefficient of determination, the relationship between PCI and IRI is quite strong. The value of $\mathrm{R}^{2}$ of 0.59 indicates that $59.0 \%$ of PCI value has an IRI value, and R-value is -0.768 , which means that the correlation level of these two parameters is strong but opposite.

\section{References}

1. ARRB Group, User Manual Roughometer III, Victoria : ARRB Group Ltd (2009)

2. ASTM D6433, Standart Practice for Roads and Parking Lots Pavement Condition Index Surveys

3. ASTM E1926, Standart Practice for Computing International Roughness Index of Roadsfrom Longitudinal Profile Measurements

4. Djakfar, Ludfi et al, Evaluation of Road Roughness and Road Deterioation, Jurnal Transportation, 3 No. 3 (2013)

5. Sinurat, Doan and Medis Surbakti. Analisis Perbandingan Nilai IRI Berdasarkan Variasi Rentang Pembacaan Naasra, Jurnal Teknik Sipil USU, 3, No 3 (2014) [in Indonesian]

6. Manurung, Ardita dkk, Perhitungan Surface Distress Index (SDI) Menggunakan Data Hawkeye, 18th Confrence FSTPT (2015)

7. Mubaraki, Muhammad, Study Relationship between Pavement Surface Distress and Roughness Data, MATEC Web of Conferences 81, 02012 (2016)

8. Nikolaides, Athanassios, Highway Engineering Pavement, Materials and Control of Quality, New York : CRC Press (2015)

9. O. S Abiola et al, Predicting Visual Pavement Score from International Roughness Index, International Conference on Biological Civil and Environmental Engineering (2014)

10. Shahin, M. Y, Pavement Management for Airport, Road and Parking Lots, New York : Champan\& Hall (1994) 
11. Stephen A. Arhin et al, Predicting Pavement Condition Index Using International Roughness Index in a Dense Urban Area, Journal of Civil Engineering Research 5(1) : 10-17

12. Suherman, Studi Persamaan Korelasi antara Ketidakrataan Permukaan Jalan dengan Indeks Kondisi Jalan, Jurnal Teknik Sipil, 8 No. 3 (206-214) (2008) [in Indonesian]

13. Suryoto et al, The Evaluation of Functional Performance of National Roadway UsingThree Types of Pavement Assessment Methods, SCESCM 2016 (2016)

14. Suwardo and Sugiharto, Tingkat Kerataan Jalan Berdasarkan Alat Rolling Straight edge untuk mengestimasi pelayanan jalan,. Universitas Gajah Mada: Yogyakarta (2004) [in Indonesian]

15. Tata Cara Survei Kerataan Pemukaan Perkerasan Jalan dengan Alat Ukur Kerataan NAASRA, SNI 03 3426 - 1994. (1994) [in Indonesian] 